Rev Med Chile 2011; 139: 36-44

\title{
Teaching of Medical Ethics: Students' perception in different periods of the course
}

\author{
DÉBORAH PIMENTEL ${ }^{1}$, CARLA BARBOSA DE OLIVEIRA ${ }^{1}$, \\ MARIA JÉSIA VIEIRA ${ }^{2, a}$
}

'Departamento de Medicina da Universidade Federal de Sergipe.

${ }^{2}$ Núcleo de Pós Graduação em Medicina da Universidade Federal de Sergipe ${ }^{a}$ Nurse, $\mathrm{PhD}$.

Recibido el 23 de noviembre de 2009, aceptado el 29 de noviembre de 2010.

Correspondência: Dra. Déborah Pimentel. Praça Tobias Barreto 510-1208, bairro São José, Aracaju-Sergipe-Brazil. CEP 49015-130. Phone: 55793214 1948. Fax: 557932318372

E-mail: deborah@infonet. com.br

\begin{abstract}
Background: Medical Ethics is structured to guide doctors towards a better professional practice. However, its teaching in medical schools seems to be neglected. Aim: To evaluate the perception of Federal University of Sergipe medical students about ethical conflicts during their academic practice, in two different periods of a medical course. Material and Methods: A cross-sectional, analytic and observational study. Using a qualitative approach, analytic categories were identified using an open questionnaire answered by two groups of students, before and after attending the medical ethics course. Results: In everyday practice, the participants referred embarrassment in front of patients. When considering the relationship with the professional/professor, they identified negligence and conflicts of interests in their practice. The students also detected bad infrastructure and professional relationship in public services, when compared to private ones. The conflicts experienced by the students in their own practice were insecurity, inability to cope with patients' problems and inadequate perception of medical confidentiality limits. According to the respondents, contribution of ethics teaching varied from adequate, when it was effective to orient their practice and provide confidence, to inadequate or absent because of an overall superficial approach. Conclusions: Major deficiencies related to the teaching of medical ethics were identified, pointing to the need to change current medical education model.
\end{abstract}

(Rev Med Chile 2010; 139: 36-44).

Key words: Education, medical, undergraduate; Ethics, medical; Students, medical.

\section{Percepciones de los estudiantes acerca de la enseñanza de ética médica}

Antecedentes: La ética médica debería guiar a los médicos hacia una mejor práctica profesional. Sin embargo, se enseña deficientemente en las escuelas de medicina. Objetivo: Identificar las percepciones de un grupo de estudiantes de medicina acerca de los conflictos éticos durante su práctica profesional en dos periodos distintos de un curso de medicina. Material y Métodos: Se efectuó un estudio transversal con un grupo de estudiantes de medicina que habían recibido el curso de bioética y otro grupo que no había recibido el curso. Ambos grupos respondieron un cuestionario abierto acerca de los conflictos que vivieron al enfrentar pacientes. Resultados: En la práctica diaria, los alumnos relataron sentir vergüenza al enfrentar pacientes. 
Acerca de su relación con los profesores, notaron negligencia y conflictos de intereses en su práctica. Los alumnos también detectaron una mala infraestructura y relación entre profesionales en servicios públicos, al ser comparados con clínicas privadas. Los conflictos que relataron los alumnos fueron inseguridad, incapacidad de enfrentar con los problemas de los pacientes y una percepción inadecuada de la confidencialidad médica. Los alumnos consideraron que la contribución de enseñar ética fluctuó desde ser adecuada cuando orientó su práctica profesional y les dio confianza hasta inadecuada o ausente, debido a ser enseñada en forma superficial. Conclusiones: Se identificaron las principales deficiencias en la enseñanza de ética médica, señalando la necesidad de cambiar el modelo educacional utilizado actualmente.

\section{The problem}

$\mathrm{H}$ uman behavior is a complex entity, and regulations and laws have always been conceived to guide men's behavior in accordance to what is expected for one specific society. Since Hippocrates, medicine practice has expressed formal concern about moral procedures and respect for life. These were the beginnings of Medical Ethics.

The medical professional is subjected to preestablished ethical standards that guide his/her conduct in the different activities he/she may be exposed, and ethical discussions have been included as a specific discipline in the medical course curriculum in some, but not all universities ${ }^{1,2}$.

Ethics and moral are complementary terms. Ethics, from the Greek ethos, means "way of being", "character" and moral, from the Latin mor or moris, means "usual", i.e., a set of standards or rules acquired by man by ordinary use $\mathrm{e}^{3,4}$.

Professional Ethics or Deontology includes the guiding principles for professionals when interacting with patients, other professionals and the institutions where they work. These principles are limited to professional environment and have specific standards, such as the Brazilian Medical Ethics Code, established from discussions between doctors and society and approved by the Federal Council of Medicine $e^{2,5,6}$.

For some authors ${ }^{1}$, the concept of Medical Ethics should prioritize medical practice. They understand that the Medical Ethics Code is no longer enough to guide the physician behavior. In an increasingly complex society, medical decisions go beyond purely cognitive aspects, so overrated in academia. It seems crucial to focus on medical education for ethics topics inclusion, inserting most of the problems students will potentially face during professional life ${ }^{7}$. Technical skills must be accompanied by ethical values early in medical education.

It is known that in many universities in Brazil, in their traditional medical course curriculum, Bioethics is not yet included as a discipline to guide the acquisition of abilities that allow the student to identify and analyze ethical problems yet. Only some of these themes are included in the subject of Forensic Medicine and Deontology, which prioritizes the Medical Ethics Code and the legal aspects of medical practice. Perhaps these contents are not sufficient to fulfill the needs of students relating to the ethical conflicts in their academic practice.

Therefore, a research was made to identify how medical students deal with ethical conflicts before and after the formal teaching about Medical Ethics at the discipline of Forensic Medicine and Deontology; to identify situations of ethical conflicts during the academic practice and to verify the contribution of Ethics formal courses to dealing with these conflicts.

As well, this paper, as a clipping of this research, aims only to identify the perception of Federal University of Sergipe medical students about ethical conflicts during their academic practice, in two different periods of the course.

\section{The method}

This is a cross-sectional study in regard to the Medical Ethics teaching at the Medical School of Federal University of Sergipe (UFS), in Aracaju, Brazil. An open questionnaire was used, with 19 questions regarding subjects of students' studies, motivations, methodology, disciplines that contributed to the practice experience, and ethical dilemmas they could have experienced during the course. 
The study was performed with two groups of students, corresponding to two different context units: the first one, attending the $5^{\text {th }}$ and $6^{\text {th }}$ semesters, with students who had not studied the Forensic Medicine and Deontology, and the second one, attending the 9th and 10th semesters with students who had just finished that course. The same questionnaire was applied to both groups.

The discipline Forensic Medicine and Deontology was used as a landmark for the division of the groups, since it is the only one that formally approaches ethical contents.

The students participated in the classroom, where they received the questionnair, and those who agreed to participate in the research returned it to a predetermined local.

The present article used data from a single question that asked the students to write a brief story about the most important ethical conflicts perceived in their academic practice.

This study was approved by the Research Ethics Committee of the Federal University of Sergipe and all respondents were informed about the purposes of the research and about their rights, in accordance to the regulations for research in human beings ${ }^{8}$.

The total number of questionnaires returned was $110(71.4 \%): 56$ from the first group and 54 from the second.

The first group of students was formed by 24 women and 32 men, with an age range of 19 to
27 years and mean age of 22.3 years. The second group was formed by 22 women, 31 men and one respondent who did not declare the gender, with an age range of 20 to 41 years and mean age of 24.47 years.

Data was analyzed using a technique of categorical approach of content analysis?. Individual analysis was blinded by using a strategy in which each questionnaire was coded as A or B for the first and second groups respectively and a sequential number for the students in each group. Content analysis was performed ${ }^{9}$, and each sense nucleus was identified at the registry units (words, clips of speeches), leading to the analytical pre-categories. The resulting categories were grouped by similarity and registered with their sense nucleus, regarding to those categories presence in different contexts and not to their frequency of occurrence.

\section{Results}

In view of the ethical conflicts identified by the student of both groups, the results were organized into four analysis sub-categories:

1. Conflicts involving the patient (Table 1);

2. Conflicts involving the professional / professor (Table 2);

3. Conflicts involving the structure of services (Table 3);

4. Conflicts involving their condition as students (Table 4).

Table 1. Ethical conflicts involving the patient identified by students, during the medical course

\begin{tabular}{|c|c|c|}
\hline \multirow[t]{2}{*}{ Sub-category } & \multicolumn{2}{|l|}{ Sense nucleus } \\
\hline & $\begin{array}{l}\text { The first context unit } \\
\text { (5 } 5^{\text {th }} / 6^{\text {th }} \text { periods) }\end{array}$ & $\begin{array}{l}\text { The second context unit } \\
\left(9^{\text {th }} / 10^{\text {th }} \text { periods) }\right.\end{array}$ \\
\hline $\begin{array}{l}\text { Embarrassment in front of } \\
\text { the patient }\end{array}$ & $\begin{array}{l}\text { Physical examination/anamnesis } \\
\text { Feeling of patient privacy invasion } \\
\text { Request the patient to undress himself } \\
\text { Exhibition of the patient in front of others }\end{array}$ & $\begin{array}{l}\text { Feeling of patient privacy invasion } \\
\text { Exhibition of the patient in front of others }\end{array}$ \\
\hline $\begin{array}{l}\text { The using of the patient as an } \\
\text { object of study }\end{array}$ & $\begin{array}{l}\text { The feeling of patient usage, } \\
\text { Feeling of bothering the patient } \\
\text { Many students examined few patients }\end{array}$ & $\begin{array}{l}\text { The feeling of patient usage } \\
\text { Care dehumanization }\end{array}$ \\
\hline Violence against the student & $\begin{array}{l}\text { The threat from dissatisfied patients } \\
\text { Patient who attack doctors or students }\end{array}$ & $\begin{array}{l}\text { Patient shocked by the treatment } \\
\text { Aggressive patient } \\
\text { Patient who attack doctors or students }\end{array}$ \\
\hline
\end{tabular}


Table 2. Ethical conflicts involving the professional/professor identified by students, during the medical course

\begin{tabular}{|c|c|c|}
\hline Sub-category & $\begin{array}{l}\text { Sense nucleus } \\
\text { The first context unit } \\
\left(5^{\text {th }} / 6^{\text {th }} \text { periods) }\right.\end{array}$ & $\begin{array}{l}\text { The second context unit } \\
\left(9^{\text {th }} / 10^{\text {th }} \text { periods) }\right.\end{array}$ \\
\hline $\begin{array}{l}\text { Neglect/ } \\
\text { Disrespect from } \\
\text { professionals }\end{array}$ & $\begin{array}{l}\text { Lack of communication from doctors } \\
\text { and professionals to the patient } \\
\text { Neglect from professionals for the } \\
\text { patients } \\
\text { Neglect of patients signs and symptoms } \\
\text { Disrespect to the patient }\end{array}$ & $\begin{array}{l}\text { Disrespect for patients individuality } \\
\text { Indifference to patients suffering } \\
\text { Disrespect to patient autonomy } \\
\text { Failure in front of fellow doctors }\end{array}$ \\
\hline $\begin{array}{l}\text { Conflicts of } \\
\text { interest }\end{array}$ & & $\begin{array}{l}\text { Professional deviating patients from public service to } \\
\text { private clinic } \\
\text { Doctors who receive privileges from laboratories } \\
\text { Professional competition } \\
\text { Use of the profession as a mean of achieving political } \\
\text { interests }\end{array}$ \\
\hline $\begin{array}{l}\text { Inadequate } \\
\text { professor } \\
\text { attitudes }\end{array}$ & $\begin{array}{l}\text { Bad treatment of the patient } \\
\text { Bad treatment of the student } \\
\text { Arrogance } \\
\text { Lack of humanization } \\
\text { Embarrassment to patients by profes- } \\
\text { sors } \\
\text { Lack of commitment to the teaching- } \\
\text { learning process }\end{array}$ & $\begin{array}{l}\text { Lack of commitment to the patient } \\
\text { Lack of interest for the profession } \\
\text { Inadequate clinical discussion with medical students in } \\
\text { front of patients } \\
\text { Bad mood of teachers } \\
\text { Arrogance } \\
\text { Bad treatment of the patient } \\
\text { Discouragement with the choice of specialty } \\
\text { Critical of colleagues in front of patient }\end{array}$ \\
\hline
\end{tabular}

Table 3. Ethical Conflicts identified by students, during the Medical course, involving the structure of services

\begin{tabular}{|c|c|c|}
\hline \multirow[t]{2}{*}{ Sub-category } & \multicolumn{2}{|l|}{ Sense nucleus } \\
\hline & $\begin{array}{l}\text { The first context unit } \\
\left(5^{\text {th }} / 6^{\text {th }} \text { periods) }\right.\end{array}$ & $\begin{array}{l}\text { The second context unit } \\
\left(9^{\text {th }} / 10^{\text {th }} \text { periods) }\right.\end{array}$ \\
\hline $\begin{array}{l}\text { Disruption of } \\
\text { health services }\end{array}$ & $\begin{array}{l}\text { Lack of organization of care. } \\
\text { Lack of material. } \\
\text { Defective equipment. }\end{array}$ & $\begin{array}{l}\text { Lack of supplies necessary for treatment of needy patients } \\
\text { Services that do not meet the demand } \\
\text { Services where the patients' care is done by students } \\
\text { without monitoring } \\
\text { Lack of compliment of working hours } \\
\text { Lack of material } \\
\text { Defective equipment } \\
\text { Bureaucracy }\end{array}$ \\
\hline $\begin{array}{l}\text { Attendance } \\
\text { at public and } \\
\text { private services }\end{array}$ & $\begin{array}{l}\text { Difficult relationship with public service } \\
\text { and private health enterprise }\end{array}$ & $\begin{array}{l}\text { Poor attendance at the public service when compared to } \\
\text { the private services }\end{array}$ \\
\hline
\end{tabular}


Table 4. Ethical Conflicts identified by students, during the Medical course, involving their condition as students

\begin{tabular}{|c|c|c|}
\hline \multirow[t]{2}{*}{ Sub-category } & \multicolumn{2}{|l|}{ Sense nucleus } \\
\hline & $\begin{array}{l}\text { The first context unit } \\
\left(5^{\text {th }} / 6^{\text {th }} \text { periods) }\right.\end{array}$ & $\begin{array}{l}\text { The second context unit } \\
\left(9^{\text {th }} / 10^{\text {th }} \text { periods) }\right.\end{array}$ \\
\hline Insecurity & $\begin{array}{l}\text { Students inexperience } \\
\text { Students shyness } \\
\text { Do not know what to do due to } \\
\text { ignorance } \\
\text { Students inability to help the patient }\end{array}$ & $\begin{array}{l}\text { Students shyness } \\
\text { Fear of dealing with the unknown } \\
\text { Fear of making mistakes. } \\
\text { Inability to help the patient. } \\
\text { Do not know what to do in the practice } \\
\text { In regard to the issuing of medical certificates. }\end{array}$ \\
\hline Medical secrecy & $\begin{array}{l}\text { Students, difficulty in dealing with } \\
\text { patients' secrets }\end{array}$ & Students difficulty in dealing with patients' secrets \\
\hline $\begin{array}{l}\text { Lack of skills in } \\
\text { relationship/ } \\
\text { communication }\end{array}$ & $\begin{array}{l}\text { Lack of guidance from professors to } \\
\text { students } \\
\text { Difficulty of patient communication }\end{array}$ & $\begin{array}{l}\text { Differing of opinions among professionals. } \\
\text { Controversial therapy } \\
\text { Difficulty in communicating bad news. } \\
\text { Difficulty in approaching the patient. } \\
\text { Do not understand the patient's language. } \\
\text { Difficulties in relationships with patient's relatives. } \\
\text { Difficulty with colleagues and professor relationships. }\end{array}$ \\
\hline
\end{tabular}

\section{Discussion}

Frequently the relationship student-patient has been considered merely technical, depersonalized and sometimes troubled, bringing negative stress to the student. It was observed (Table 1) a similarity between the two groups regarding these conflicts, either with the student's acts invading the patient's privacy or when they are victims of patient's violence or harassment.

The results of the present research are, most of the time, coincident with the ones of other authors cited in literature.

In these two context units, the contact with patients resulted in conflicts at some point during medical training. Students demonstrated a variety of fears while relating to the patient, probably due to lack of experience and insecurity in medical practice $^{10-12}$.

For students in the 5th and 6th semesters, it seems to be more significant, for collecting the first medical history and performing the first physical examination usually awake emotional reactions in students and make them anxious ${ }^{12,13}$ :

Feeling of bothering the patient, insecurity and difficulty to examine the patient when it is necessary to undress him $(A 11,5)$.
The feeling of using the patient as an object for study is also named as a nuisance to the students, creating feelings of being invasive or abusive to their fellow-being ${ }^{11-14}$ :

Patients were also a source of conflict for having hostile attitudes when facing different situations. It seems to reflect changes in society, where patients are not as "patient" as before ${ }^{15}$. Real life shows that the patient out of the books is a human being who suffers, complains, does not always cooperate and requires a quick and effective solution for his/her problems ${ }^{16}$ :

I was threatened by a patient for delaying to attend him. I was almost beaten $(A 8,6)$.

The results show that the interaction with various professionals allows having experiences in many types of conflicts, particularly as mutual respect, which is missing in medical education. In the two contexts units we found an inadequate attitude of professional/ professor, regarding to the relationship with patients. In second unit, however, students made it clearer, perhaps because they have already been exposed to specific discussions about that topic (Table 2).

Overcoming these difficulties relies on the professor's aid, because it is during academic background that the students must obtain the resources 
they need to deal with human dimension of therapeutic relationship. A professor's example seems to be essential in building up professional identity, which enhances the patient-doctor relationship ${ }^{(10)}$.

However, important conflicts involving professors were observed. There are unethical and inhuman attitudes by health professionals in general and by professors, and these models are incorporated into the student's practices as a standard for their professional behavior ${ }^{7,15}$.

Some professors do not consider patient autonomy ${ }^{17,18}$ and do not act within recommended ethical and humanistic approaches:

In the investigation of certain conditions, it is not questioned whether the patient wants to be submitted to that procedure $(A 11,9)$.

... professors seem to forget that they are facing the patients and talk about the disease (...) without caring about the human being in front of them (A22, 10).

In regard to that situation, some authors ${ }^{18-20}$ report patient perceptions about the treatment received at the University Hospitals and reveal that the visits at the bedside are the only negative aspect, once they feel themselves like subjects under study. There must be ways to teach new doctors without embarrassing the patient. On the other hand, there are researches in which the patients relate they accept the student's presence in anamnesis as well as in the physical examination, as long as they do not participate in the decisions at diagnosis and treatment ${ }^{11}$.

Situations of abuse, defined as "negative actions or words, unnecessary and avoidable, inflicted by one person to another or others" ${ }^{(21)}$ were indirectly referred, but such circumstances are very common, and literature $\mathrm{e}^{21,22}$ refers that many students reported abuse at some time point at the course.

... the occurrence of maltreatment of patients and students from professors $(A 1,5)$.

Teachers' lack of compromise is also referred by students. They identify professors without updated teaching material, showing uncommitment to teaching process and frustrating student expectations about school contribution to their medical career with interesting and motivating teaching situations $^{10,23}$ :

Some (professors) were arrogant, pretending they were almighty, without compromise with education $(A 3,9)$.

... arrived late or missed the clinic (A 21.9).
The relationship within the workplace was perceived as unethical and marked by a spirit of competition ${ }^{(24)}$ :

Authoritarian personality towards other professionals $(A 18,5)$.

Professors do not miss any opportunity to lower a workfellow's image $(A 7,9)$.

Interest conflict was identified by second unit students, referring to the influence of nontechnical factors in medical prescriptions ${ }^{(25-27)}$ and mercantilist attitude of some professionals ${ }^{(28)}$ :

Doctors prescribe only one type of medicine and receive privileges from laboratories, like free travel to medical conventions, help in job dispute between professionals, patient referral to their private offices ... (A19, 9).

In this context, learning motivation can be influenced by the professor and the existence of conflicts in this relationship may cause depression and discouragement to studying and having a good relationship with patients ${ }^{13}$ :

My doctor ideal, as a person who is concerned about others' suffering, does not exist here. Doctors are insensitive. Patients are treated in an inhuman way. I see ethics as respecting the patient as a human being, and not as legal principles. Medicine has become a profession like any other $(A 32,6)$.

The authors ${ }^{21}$ remind us that when the professor gives some freedom, security and confidence to the students, they feel more stimulated, while the aggressive response from him would be an obstacle to learning.

The students point out the lack of physical and organizational structure observed in public services and their anxieties about the quality of learning, considering the usual shortage of conditions for implementing knowledge. Also here, students of second unit relate problems more clearly, even identifying the care provided by unsupervised students (Table 3 ).

Medical schools should provide an infrastructure with adequate materials and professors committed to guide, encourage and foster students' learning based on humanism and ethics ${ }^{23}$. The overall situation is, inversely, the lack of commitment of professors and of hospital infrastructure to face student needs and aspiration ${ }^{29}$ :

In addition, the respondents have conflicts with their role as a student.

As medical students, they may fear specific responsibilities that they are not prepared to deal 
with. This may be a matter of lack of experience or technical skills, or it may happen because of shyness (Table 4).

The expectation to be a good doctor stumbles on the frightening prospect of increasing responsibility associated with the fear of making mistakes or not knowing what to do in the face of several situations ${ }^{12,23}$ :

The relationship with patients' relatives is sometimes interpreted as an obstacle to a good relationship with the patient:

When the accompanist does not allow the patient to express by him/herself or when he/she inquires us about what the patient told us (A12, 9).

Facing death brings suffering, the students become aware or discover that it cannot always be avoided. The contact with chronic or terminal patients awakens in students a sense of impotence, and they realize that they do not really know how to deal with these situations ${ }^{12,13,30}$ :

... to learn how to deal with children suffering from cancer and poor prognosis $(A 21,10)$.

Doubts about the confidentiality, body of character substantive in the doctor-patient relation ${ }^{(24)}$, created discomfort for some students:

Patient who refuses medical recommendations and I did not know whether to inform the doctor, as the patient only told me secretly. $(A 1,6)$.

Patient with AIDS accompanied by the husband, whom doesn't know about it $(A 5,9)$.

The current individualistic vision discourages a listening attitude in daily relationships and makes doctors less prepared to work with subjectivity, and to develop a healthy doctor-patient relationship ${ }^{31}$.

... knowing to what extent we may/must get involved with patients' problems (A26, 9).

There are also difficulties in understanding the patient, and it is important for the doctor to try to translate their language, sometimes full of primitive signs $s^{31,32}$.

Finally, the results also show how some subjects, according to the students, clarified some ethical points, and were able to solve problems during the course $\mathrm{e}^{33}$.

In general, for the first group important relief could be felt in knowing that they are not the only ones with conflicts, that some conflicts are expected, indeed.

For the other group the guidelines are more detailed according to each situation, with some theoretical deepening missing, and some practical skills also.

There were students who did not feel assisted, in any way, by the institution with the conflicts they had to deal with, describing the school's contributions as insufficient or nonexistent.

It was observed that the teaching of ethics, as from the point of view purely deontological or understood as a guideline for dealing with moral conflicts of medical practice, constitutes a little explored field within the university, despite its great importance.

Meanwhile, society requires more and more that doctors should have ethical attitudes and a holistic view of the patient, beyond the technical training so stimulated during their course.

The failing in the ethics formation within the university brings conflicts of the magnitude previously reported. The relationships in all fields, are worn, and students, most of the time, feel helpless.

The results show major deficiencies in many respects, although a more sharp ethical conscience was evident in students from the second group, who studied Forensic Medicine and Deontology. They more often felt that they were more skilled to manage conflicts after having studied this discipline, also considering that different levels, age, and other variables must give different perceptions and experiences.

It is important to consider that the drawing of the study with different groups does not follow the maturation of the pupils throughout the course. As well, despite it is known that the students of the first group were younger and less mature than the ones of the second group, and that these factors can influence their perception and administration of conflicts, what is argued in this paper is that there is no preparation of the pupils of the first group about ethical considerations to face academic practice and patients contact, and this contact happens before they are prepared for this.

As for the second group, neither the subject Forensic Medicine and Deontology fulfils the students needs, because it is not a Bioethics specific matter, pointing to the need of Medicines courses, which have that matter as the only possibility of study of ethical subjects, to try to adjust its courses of study to contribute to the formation of the pupils and their future practice.

It is in progress another stage of the same research to identify, with the medical professionals, 
the conflicts in their practice and the contribution that the university education had to dealing with these conflicts.

Ahead of the results presented in this research, it is strengthened that there is an urgent need for greater commitment with education focused on the humanization of medical practice, with more prepared professors, better infrastructure and a curriculum reform that will prioritize the teaching of ethics.

\section{References}

1. Athanazio RA, Lemos KM, Fonseca DC, Cunha MS, Braghiroli MIFM, Almeida AM, et al. Academética: um novo método de estudo continuado sobre Ética Médica e Bioética. Rev Bras Educ Med 2004; 28: 73-8.

2. Miller S. What use are ethical codes? An analysis of three possible rationales for the use of ethical codes in medical schools and a review of the evidence relating to them. Med Educ 2000; 34: 428-9. Avaliable at: http://www3. interscience.wiley.com/cgi-bin/fulltext/119010634/ PDFSTART. [Accessed March 05, 2009].

3. Grisard N. Manual de Orientação ética e Disciplinar. Florianópolis: CREMESC; 2006.

4. Castilho EA, Kalil J. Ética e pesquisa médica: princípios, diretrizes e regulamentações. Rev Soc Bras Med Trop 2005; 38: 344-7.

5. Cohen C, Segre M. Breve discurso sobre valores, moral, eticidade e ética. Rev Bioética 1994; 2: 19-24.

6. Figueira EJG, Cazzo E, Tuma P, Filho CRS, Conterno LO. Apreensão de tópicos em Ética Médica no ensinoaprendizagem de pequenos grupos, comparando a aprendizagem baseada em problemas com o modelo tradicional. Rev Assoc Med Bras 2004; 50: 133-41.

7. Cordingley L, Hyde C, Peters S, Vernon B, Bundy C. Undergraduate medical students_exposure to clinical ethics: a challenge to the development of professional behaviours? Med Educ 2007; 41: 1202-9.

8. Conselho Nacional de Saúde. Resolução 196 de 10 de Outubro de 1996. Disponible en: http://conselho.saude. gov.br/docs/Resolucoes/Reso196.doc. [Consultado el 07 de enero de 2008].

9. Bardin L. Análise de conteúdo. Lisboa: Edições Setenta; 2006.

10. Moreira SNT, Silva CAN, Tertulino FF, Tertulino FMF, Vilar MJP, Azevedo JD. Processo de significação de estudantes do curso de Medicina diante da escolha profissional e das experiências vividas no cotidiano acadêmico. Rev Bras Educ Med 2006; 30: 14-9.
11. Beca I JP, Browne L F, Repetto L P, Ortiz P A, Salas A C. Relación estudiante-enfermo: Visión del paciente. Rev. Med. Chile 2006; 134: 955-9. Avaliable at: http://www. scielo.cl/pdf/rmc/v135n12/art01.pdf. [Acessed feb. 02, 2010].

12. Beca I JP, Browne L F, Repetto L P, Ortiz P A, Salas A C . Relación estudiante de medicina-enfermo: visión de los estudiantes. Rev. Med. Chile 2007, 135: 1503-9. Avaliable at: http://www.scielo.cl/pdf/rmc/v135n12/art01.pdf. [Acessed feb. 02, 2010].

13. Araújo D, Peixinho AL. Avaliação qualitativa em Medicina: experiência em propedêutica médica na UFBA, 2003. Rev Bras Educ Med 2006; 30: 20-30.

14. Mukohara K, Ban N, Sobue G, Otani T, Ymada S. Follow .The patient: process and outcome evaluation of medical students' educational experiences accompanying outpatients. Med Educ 2006; 40:158-65. Avaliable at: http://www3.interscience.wiley.com/cgi-bin/fulltext/118729356/PDFSTART [Accessed March 05, 2009].

15. Taquette SR, Rego S, Schramm FR, Soares LL, Carvalho SV. Situações eticamente conflituosas vivenciadas por estudantes de Medicina. Rev Assoc Med Bras 2005; 51: 23-8.

16. Bellodi PL, Martinho T, Massaroppe B, Martins MA, Santos MAS. Temas para um Programa de Tutoria em Medicina: uma investigação das necessidades dos alunos da FMUSP. Rev Bras Educ Med 2004; 28: 119-27.

17. Almeida HO, Alves NM, Costa MP, Trindade EMV, Muza GM. Desenvolvendo competências em comunicação: uma experiência com a Medicina Narrativa. Rev Bras Educ Med 2005; 29: 208-16.

18. León RT, Bedregal P, Shand BB. Prevalencia de problemas éticos en Servicios de Medicina, desde la perspectiva del paciente. Rev Med Chile 2009; 137: 759-65. Avaliable at: www.scielo.cl [Accessed July 12, 2009].

19. Cortopassi AC, Lima MCP, Gonçalves IJ. Percepção de pacientes sobre a internação em um Hospital Universitário: implicações para o ensino médico. Rev Bras Educ Med 2006; 30: 42-8.

20. Wiggins MN, Coker K, Hicks EK. Patient perceptions of professionalism: implications for residency education. Med Educ 2009; 43: 28-33. Avaliable at: http://www3. interscience.wiley.com/cgi-bin/fulltext/121575141/ PDFSTART [Accessed March 05, 2009].

21. Costa LSM, Pereira CAA. O abuso como causa evitável de estresse entre estudantes de Medicina. Rev Bras Educ Med 2005; 29: 185-90.

22. Berk R. Derogatory and cynical humour in clinical teaching and the workplace: the need for professionalism. Med Educ 2009; 43: 7-9. Avaliable at: http://www3. interscience.wiley.com/cgi-bin/fulltext/121575140/ 
PDFSTART [Accessed March 05, 2009].

23. Dini OS, Batista NA. Graduação e prática médica: expectativas e concepções de estudantes de Medicina do $1^{\circ}$ ao $6^{\circ}$ ano. Rev Bras Educ Med 2004; 28: 198-203.

24. Monte FQ. A ética na prática médica. Rev Bioética 2002; 10: 31-46.

25. Luiz NW, Neto FJRO, Thomaz JB. O Ato Médico. Aspectos éticos e legais. Rio de Janeiro: Rubio; 2002.

26. Molinari GJDP, Moreira PCS, Conterno LO. A influência das estratégias promocionais das indústrias farmacêuticas sobre o receituário médico na Faculdade de Medicina de Marília: uma visão ética. Rev Bras Educ Med 2005; 29: 110-8.

27. Salas SP, Osorio FM, Vial CP, Rehbein VAM, Salas AC, Beca I JP. Conflicto de intereses en la práctica clínica: Análisis ético de algunas relaciones con la industria. Rev Med Chile 2006; 134: 1576-82. Avaliable at: www.scielo. cl [Accessed January 12, 2008].

28. Gomes AMA, Moura ERF, Amorim RF. O lugar da Ética e Bioética nos currículos de formação médica. Rev Bras Educ Med 2006; 30: 56-65.
29. Castro FC. Os temores na formação e prática da Medicina: aspectos psicológicos. Rev Bras Educ Med 2004; 28 : 38-45.

30. Colares MFA, Troncon LEA, Figueiredo JFC, Cianflone ARL, Rodrigues MLV, Piccinato CE, et al. Construção de um instrumento para avaliação das atitudes de estudantes de Medicina frente a aspectos relevantes da prática médica. Rev Bras Educ Med 2002; 26: 194-203.

31. Grosseman S, Patrício ZM. A relação médico-paciente e o cuidado humano: subsídios para promoção da educação médica. Rev Bras Educ Med 2004; 28: 99-105.

32. Mirza DM. The language of instruction. Med Educ 2009; 43: 99. Avaliable at: http://www3.interscience.wiley.com/ cgi-bin/fulltext/121575140/PDFSTART [Accessed March 05, 2009].

33. Goldie J, Schwartz L, Morrison J. A process evaluation of medical ethics education in the first year of a new medical curriculum. Med Educ 2000; 34: 468-73. Avaliable at: http://www3.interscience.wiley.com/cgi-bin/ fulltext/119010624/PDFSTART [Accessed March 05, 2009]. 